\title{
EFEKTIVITAS LAYANAN PENGUASAAN KONTEN MENGGUNAKAN STRATEGI PROBLEM SOLVING UNTUK MENINGKATKAN SELF MANAGEMENT SISWA DALAM BELAJAR (STUDI EKSPERIMEN TERHADAP SISWA SMAN 13 PADANG)
}

\author{
Berliantika Putri Aswir ${ }^{1)}$, Firman ${ }^{2)}$, Syahniar ${ }^{3)}$ \\ Jurusan Bimbingan dan Konseling \\ FIP Universitas Negeri Padang \\ Email : firman@konselor.org
}

\begin{abstract}
Abstrak
Self Management dalam belajar merupakan keterampilan yang harus dimiliki setiap siswa. Salah satu upaya yang dilakukan oleh guru BK untuk meningkatkan self management siswa dalam belajar yaitu melalui layanan penguasaan konten. Namun pada kenyataannya, upaya yang diberikan oleh guru BK secara konvensional belum mencapai sasaran sesuai yang diharapkan. Penelitian ini bertujuan untuk melihat efektivitas layanan penguasaan konten menggunakan strategi problem solving untuk meningkatkan self management siswa dalam belajar di sekolah.

Penelitian ini menggunakan pendekatan kuantitatif. Jenis penelitian ini adalah Quasi Eksperiment rancangan The Non Equivalent Countrol Group. Subjek penelitian adalah siswa kelas X2 dan X6 SMA N 13 Padang. Teknik pengumpulan data menggunakan kuisioner, kemudian dianalisis dengan teknik uji beda ( $t$ test) menggunakan bantuan program Statistical Product and Service Solution (SPSS) versi 20.0 dan Microsoft Excell 2007.

Hasil penelitian menunjukkan layanan penguasaan konten menggunakan strategi problem solving dapat meningkatkan self management siswa dalam belajar. Selanjutnya, pelaksanaan layanan penguasaan konten menggunakan strategi problem solving lebih efektif dalam meningkatkan self management siswa dalam belajar dari pada layanan penguasaan konten secara konvensional. Secara khusus temuan dari penelitian ini yaitu: (1) terdapat perbedaan yang signifikan pada self management siswa dalam belajar kelompok eksperimen sebelum dan sesudah diberikan layanan penguasaan konten menggunakan strategi problem solving, (2) tidak terdapat perbedaan yang signifikan pada self management siswa dalam belajar kelompok kontrol yang diberikan layanan penguasaan konten secara konvensioanl, (3) terdapat perbedaan yang signifikan pada self management siswa dalam belajar antara kelompok eksperimen dan kelompok kontrol. Hal ini menunjukkan bahwa layanan penguasaan konten menggunakan strategi problem solving efektif untuk meningkatkan self management siswa dalam belajar. Dengan demikian, guru bimbingan dan konseling diharapkan dapat meningkatkan self management siswa dalam belajar melalui pelaksanaan layanan penguasaan konten menggunakan strategi problem solving yang tentunya tidak terlepas dari bantuan dari berbagai pihak terkait.
\end{abstract}

Kata kunci: Layanan Penguasaan Konten, Strategi Problem Solving, Self Management dalam Belajar.

\section{PENDAHULUAN}

Belajar merupakan upaya untuk menguasai sesuatu yang baru (Prayitno, 2004:71). Belajar bertujuan agar potensi yang ada pada diri siswa dapat berkembang secara optimal. Setiap manusia memiliki berbagai potensi dan kemampuan yang tersembunyi didalam diri mereka. Kemampuan belajar siswa untuk mencapai hasil belajar yang baik sangatlah tergantung pada bagaimana siswa dapat memanajemen dirinya, yaitu mengatur, mengarahkan dan merencanakan kegiatan belajar secara teratur, sehingga tujuan belajar yang ditargetkan dapat tercapai, yang mana tujuannya ialah mencapai nilai yang maksimal dan naik kelas.
Hamzah B. Uno (2006:219) menyatakan bahwa manajemen diri adalah perilaku siswa yang bertanggung jawab terhadap pengaturan segala perilakunya sendiri dengan tujuan agar siswa bisa lebih mandiri, lebih indipenden, lebih mampu memprediksi masa depannya.

Berdasarkan penjelasan di atas manajemen diri merupakan suatu instrumen dalam diri sendiri yang berfungsi sebagai power yang akan menggerakkan diri untuk memperoleh pribadi yang sempurna, yaitu pribadi yang mampu mengendalikan segala bentuk kemauan untuk mewujudkan segala keinginan yang telah direncanakan.

Tujuan tersebut dapat dicapai apabila tujuan jelas bentuknya dan jelas juga cara untuk mencapainya. Tujuan yang dimaksud ialah meningkatkan manajemen diri siswa dalam 
belajar. Hal ini menuntut siswa yang bersangkutan menyusun strategi mencapai tujuannya. Jika tujuan sudah jelas dan cara mencapainya juga telah tersusun dengan sempurna maka tingkah laku siswa tersebut lebih terkontrol dan terarah kepada pencapaian tujuan. Selanjutnya siswa dapat mengembangkan tingkah laku positif dirinya untuk memperoleh tujuan yang lebih sempurna.

Berdasarkan hasil wawancara dengan 7 siswa SMAN 13 Padang pada tanggal 20 Januari 2016, yang mana wawancara dilakukan seperti diskusi kelompok dan pertanyaan dari setiap responden saling berkaitan dari setiap jawabannya, sehingga responden tidak menyadari sudah menjawab setiap pertanyaaan dari pedoman wawancara yang sudah disiapkan. Dari hasil wawancara disimpulkan bahwa siswa tidak ada membuat jadwal belajar sendiri, lebih sering bermain dari pada belajar, sering terlambat mengumpulkan tugas bahkan tidak mengerjakannya sama sekali, tidak memahami bagaimana belajar yang baik, sering terlambat masuk kelas karena sarapan di sekolah terlebih dahulu dan tidak ada persiapan dalam menghadapi ulangan. Dengan kata lain, mereka kurang mampu dalam mengelola diri masingmasing khususnya dalam belajar.

Kemudian, hasil wawancara yang diperoleh dari koordinator BK SMA N 13 Padang pada tanggal 21 Januari 2016, diketahui bahwa ada dua kelas dari kelas $X$ yang dikelompokkan dalam self management rendah. Kelas tersebut adalah kelas X2 dan kelas X6. Hal ini dibuktikan dengan rendahnya rata-rata nilai kedua kelas tersebut jika dibandingkan dengan kelas lainnya, kemudian kekompakan dari kelas tersebut kurang, hampir semua guru mata pelajaran mengeluh kepada guru BK akan kelakuan siswa dari kedua kelas tersebut yang tidak mengerjakan tugas, datang terlambat, sering keluar masuk kelas dan duduk di kantin saat jam pelajaran dengan berbagai macam alasan, tidak membawa peralatan belajar dan sering terlambat dalam menyerahkan tugas.

Guru BK atau konselor sekolah mempunyai tugas dan tanggungjawab untuk membantu meningkatkan self management siswa dalam bentuk layanan bimbingan dan konseling. Prayitno (2004:26) berpendapat "pelayanan konseling bertujuan kepada kondisi pribadi yang mandiri, sukses, dan berkehidupan efektif dalam kesehariannya". Kondisi-kondisi yang dimaksudkan itu tidak datang dengan sendirinya, melainkan melalui pengembangan yang terarah, yaitu melalui pendidikan yang di dalamnya terdapat pelayanan konseling. Salah satu layanan yang diberikan guru BK di sekolah yaitu layanan penguasaan konten.

Pemberian layanan penguasaan konten (PKO) merupakan layanan bantuan kepada individu (sendiri ataupun kelompok) untuk menguasai kemampuan atau kompetensi tertentu melalui kegiatan belajar (Prayitno, 2012:89).

Inti dari pelaksanaan manajemen diri adalah memecahkan masalah. Di era global, kemampuan berpikir kritis, kreatif, logis, dan rasional semakin dibutuhkan. Oleh sebab itu, dalam mengarahkan siswa memanajemen dirinya dalam proses pembelajaran guru BK hendaklah memberikan strategi yang tepat seperti strategi pemecahan masalah.

Menurut J.W. Santrock (2012:316) problem solving (pemecahan masalah) adalah mencari cara yang tepat untuk mencapai suatu tujuan. Ada empat langkah dalam memecahkan masalah yaitu (1) mencari dan memahami masalah, (2) menyusun strategi pemecahan masalah yang baik, (3) mengeksplorasi solusi, (4) memikirkan dan mendefinisikan kembali problem dan solusi dari waktu ke waktu.

Nuzliah (2015) dalam hasil penelitiannya yang berjudul Kontribusi Motivasi Belajar, Kreativitas terhadap Problem Solving (Pemecahan Masalah) Siswa di SMP N 29 Padang mengatakan (1) motivasi belajar siswa secara umum berada pada kategori rendah, (2) kreativitas siswa secara umum berada pada kategori sedang, (3) problem solving (pemecahan masalah) siswa dalam belajar berada pada kategori sedang, (4) terdapat kontribusi mahasiswa belajar dengan problem solving (pemecahan masalah) siswa dalam belajar, (5) terdapat kontribusi kreativitas dengan problem solving (pemecahan masalah) siswa dalam belajar, dan (6) terdapat kontribusi kreativitas, motivasi belajar terhadap problem solving (pemecahan masalah) siswa dalam belajar.

Selanjutnya Vinda Chairunnisa (2013) dalam hasil penelitiannya yang berjudul Hubungan Manajemen Diri dengan Hasil Belajar Siswa di SMA N 1 Sungayang menyatakan terdapat hubungan yang signifikan antara manajemen diri dengan hasil belajar siswa di SMA N 1 Sungayang, Kab. Tanah Datar.

Berdasarkan uraian permasalahan di atas, peran guru BK sangat dibutuhkan untuk menerapkan layanan bimbingan dan konseling salah satunya melalui layanan penguasaan konten menggunakan strategi problem solving untuk meningkatkan self management siswa dalam belajar.

\section{METODOLOGI}

Penelitian ini menggunakan pendekatan kuantitatif. Jenis penelitian ini adalah Quasi Eksperiment rancangan The Non Equivalent Countrol Group. Subjek penelitian meliputi siswa kelas X2 dan X6 SMAN 13 Padang yang 


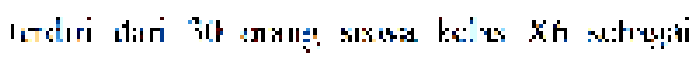

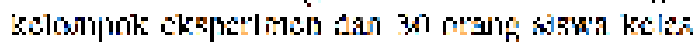

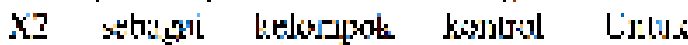

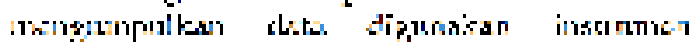

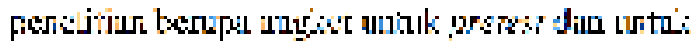

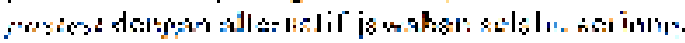

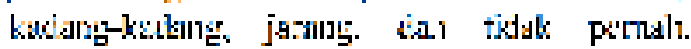

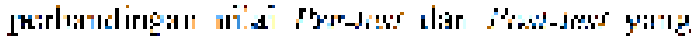
d.kinukskal olch Sulsrsimi Arikuts

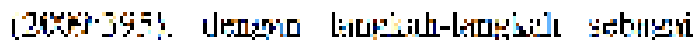
lucilkıL.

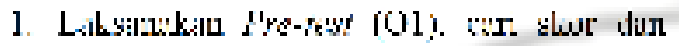

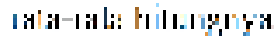

IJm.y. skor ideal - skor tentingaj x jurıluh

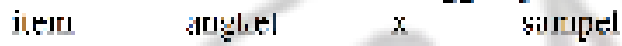
$\mathrm{r}-\frac{r}{*} \mathrm{X} 1000$

Kolesaryan:

$\mathrm{P}-$ pilicrtas:

$\mathrm{I}$ - lick ו. بrisi

$\mathrm{N}-$ jumbla samps!

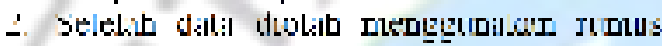
statistik kenudian dictspkan hrikia

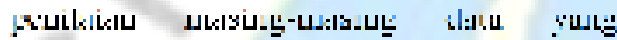

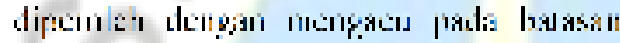
yane d:lis:nuliukan olsh A A

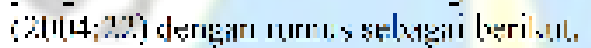
Into J'r.Juh kilo:upok

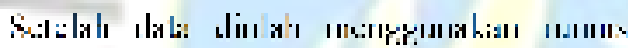
staristik kanudian ditctapkun xiteria peuilıiun

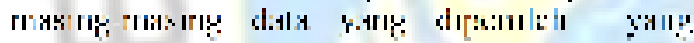
mannasu icpoda ba:asar yang dikemukakn

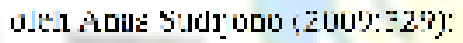

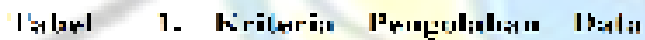
Joskriprif Hasil Penelitiam

\begin{tabular}{|c|c|c|}
\hline $\begin{array}{c}\text { Kelas } \\
\text { Interral }\end{array}$ & & W Skor \\
\hline $18: 225$ & Sildęal 11,14k & 战 \\
\hline $157 \quad 165$ & Iiluk & 68 8. \\
\hline $117-152$ & Cukup Br.ik & 5267 \\
\hline $81-110 i$ & Tidak Baik & $36-51$ \\
\hline $4 \div \quad 60$ & Snr:anr ${ }^{-}$dak Rniir & $\therefore 3.5$ \\
\hline
\end{tabular}

Ṡelanjang

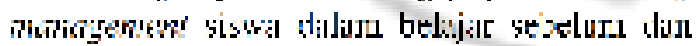

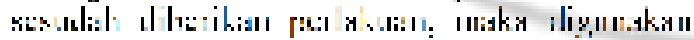

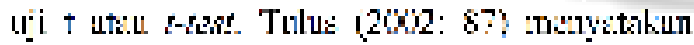

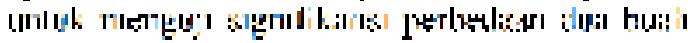

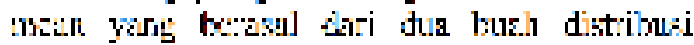

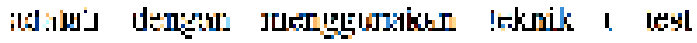

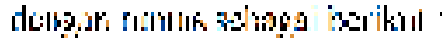

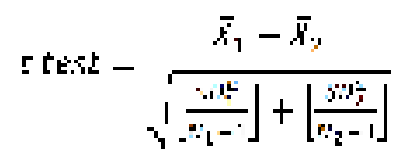

Fivers.r.gut,

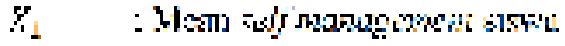

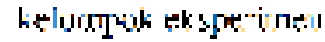

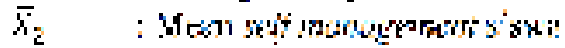

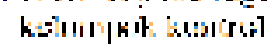

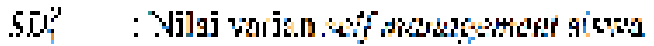

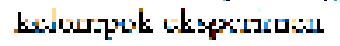

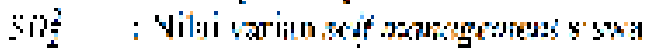
belonerak knstiol

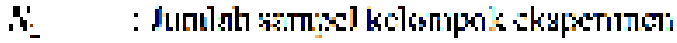

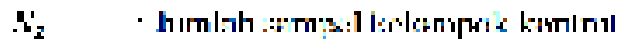

Ilasi perhitungan terachul rlibuntiggker

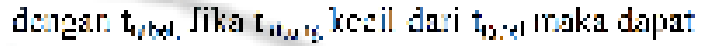

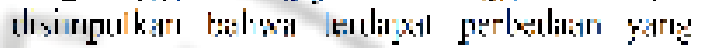

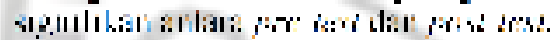

II.4SIL

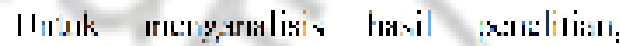

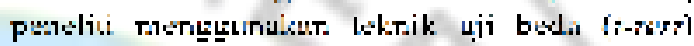

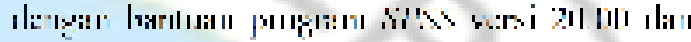

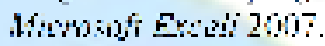

1. Pengujian Hipotesia Pertaran

TTipo:csis perrmas suin reriaptat

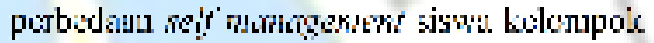

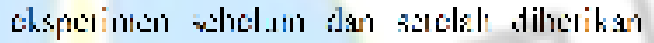

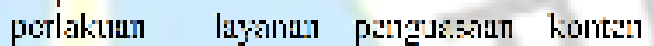

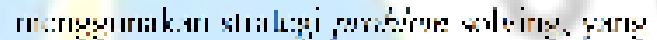

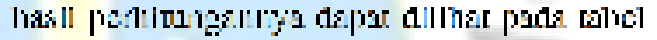
berukul iui

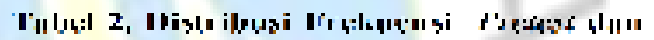
Pusriext Self Murofgentert Sista dalan Itulujaı Kulonipok Likspurinueı

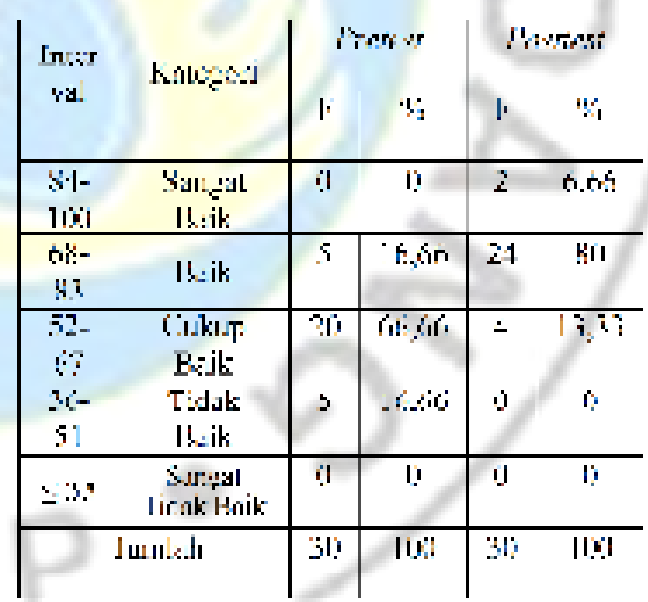

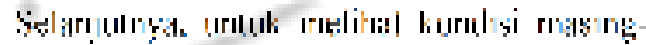

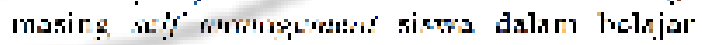

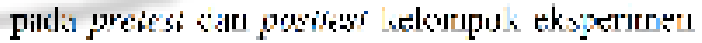

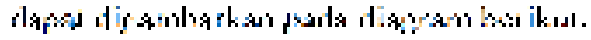

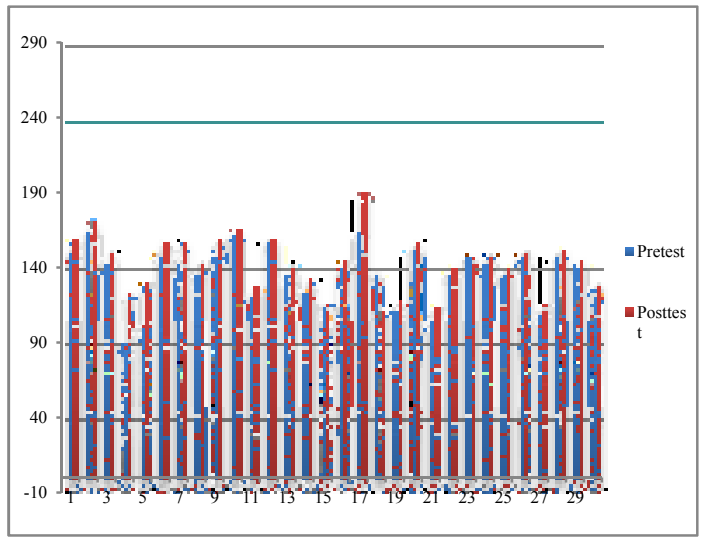




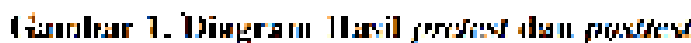

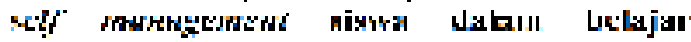
kslowpuk k ks perimen

Sercentare th, berdase.kan Jiz l u ui boda

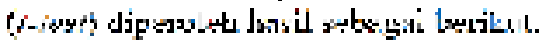

Tuhat :- Ilasil Analixiv Ilji s-stext l'erlonalum Self : Warausenent Siswa dalam Belajar pada

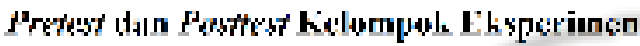

\begin{tabular}{|c|c|c|c|c|c|c|}
\hline 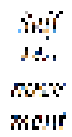 & 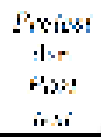 & Ja'Yh & 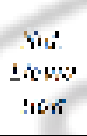 & 4 & Ed & $\begin{array}{l}\text { Sis. } \\
\because 8 \\
-18 \\
11\end{array}$ \\
\hline $\begin{array}{l}\text { L.. } \\
\text { |ainl }\end{array}$ & Theres & $\begin{array}{l}1.7 .4 \\
1:\end{array}$ & 15.277 & \multirow[b]{2}{*}{$\begin{array}{l}34 \\
: 1\end{array}$} & \multirow{2}{*}{58} & \multirow{2}{*}{ וגיו } \\
\hline$\underset{\text { jeir }}{\text { Del: }}$ & Nosiin & $\begin{array}{c}11.2 .8 \\
7\end{array}$ & If:..ikz & & & \\
\hline
\end{tabular}

Dari hasil parhicungen teracbutt dipereleh

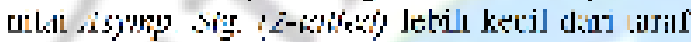

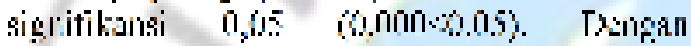

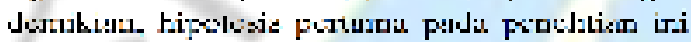

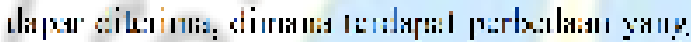

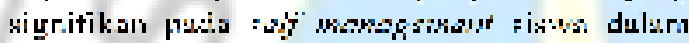

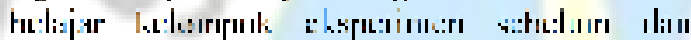
scruds.t. dibsti layant xempunsaan so:ten

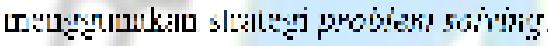

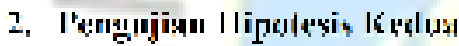

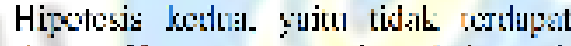

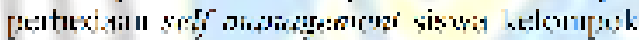
kontmol scixelur. dan satele.t. si.xerikan

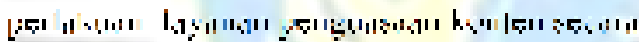
kontensio.e.l (tonple menefunaken strateg

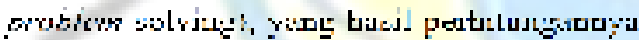

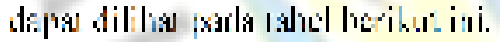

Tahal 1 Tuichihnsi Frckiurnei Proper dan perstest Self :Hanigenderst Sixust tallam Bélajar Kelominonk Konilanl

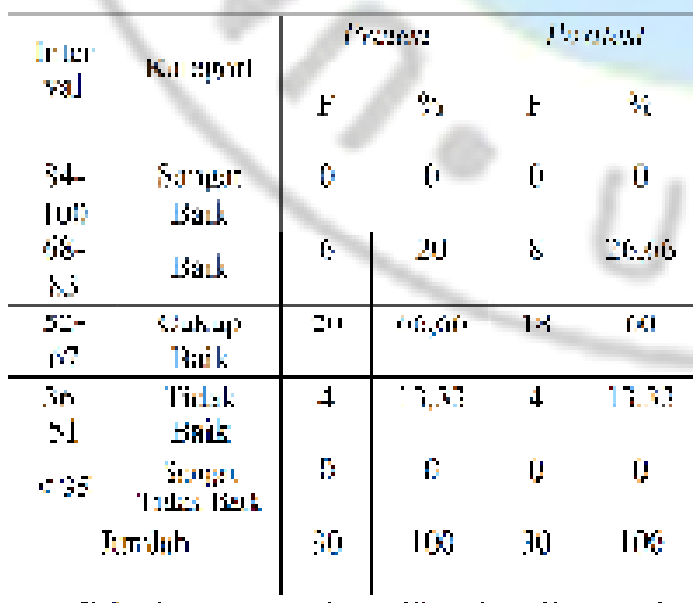

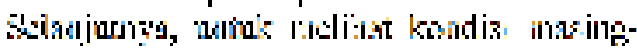

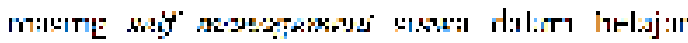

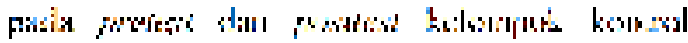

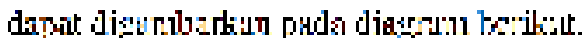

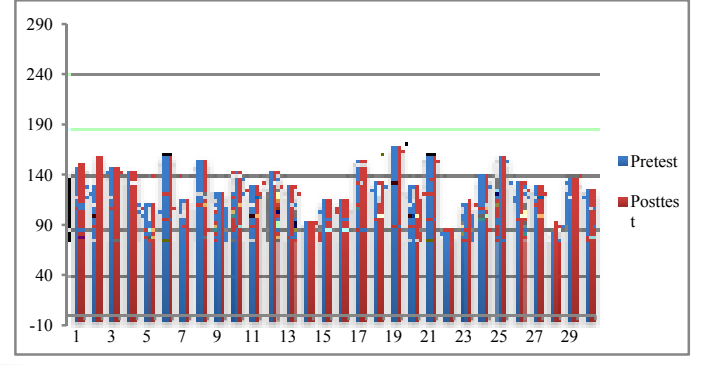

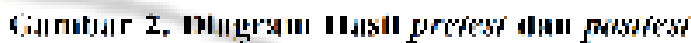
self numgenest siswa dolam belajar kilvapoh thapsiancen

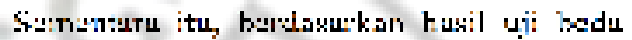

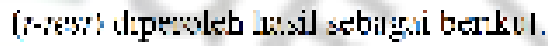

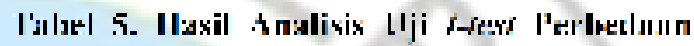
Self :Homagrwesz Siswa dalaın Belajial pada Pretest Jan Postest hiclumpuh Kontrul

\begin{tabular}{|c|c|c|c|c|c|c|}
\hline 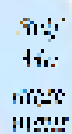 & 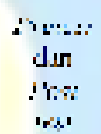 & Jic:m & 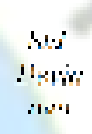 & 1 & 1 & tive \\
\hline $\begin{array}{l}\text { In } \\
\text { Inf!n }\end{array}$ & "rovt:2! & $\begin{array}{c}\text { I is. I } \\
\text { :1 }\end{array}$ & $21,13: 2$ & \multirow[b]{2}{*}{$\begin{array}{l}1: 1 \\
7:\end{array}$} & & \multirow{2}{*}{ 1: 71} \\
\hline $\begin{array}{l}\text { D:1] } \\
\text { jar: }\end{array}$ & $P /$ pifinisi & $\begin{array}{c}\text { ifn.8 } \\
7\end{array}$ & 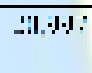 & & 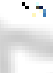 & \\
\hline
\end{tabular}

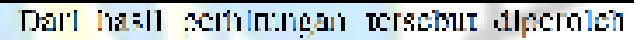

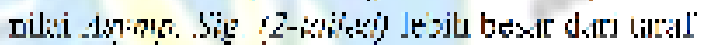
signitikansi 0,0 ing

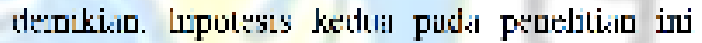

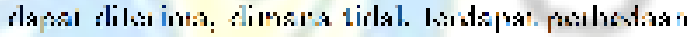
צuI

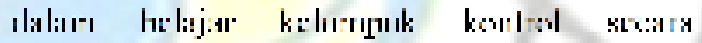
killivens rutal.

\section{Pengujian Hipotesik Kctiga}

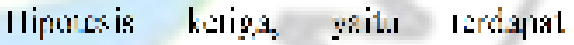

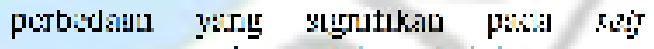

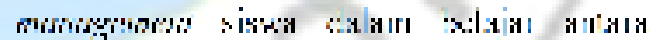

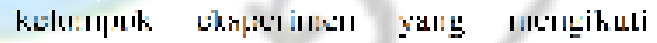

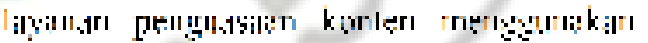

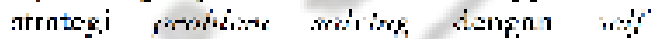

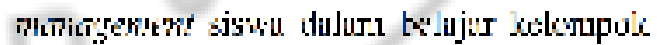

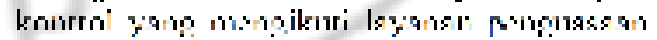

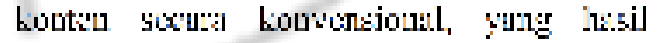

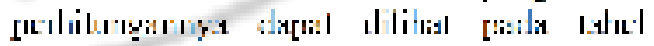
licrikit ini.

Talas G. Hasil Analișis Uji t-te.ț Scif

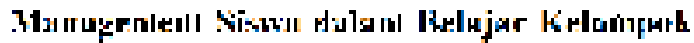
r.kepertmen dengan kicdounpek Kantret Sicrada ribirikan Perteknan

\begin{tabular}{|c|c|c|c|c|c|c|}
\hline 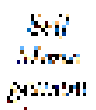 & $\begin{array}{l}\text { nue } \\
\text { ikst }\end{array}$ & Secen & 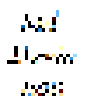 & 1 & $\mathrm{di} \mathrm{I}^{\circ}$ & $\begin{array}{c}\text { Sil } \\
\text { mil- } \\
\text { mil }\end{array}$ \\
\hline Lxls; & 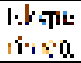 & $"\langle\overline{2}, 3\rangle$ & "A, & $\begin{array}{l}3.2 \\
24\end{array}$ & tit. & :i, ا, ו,י \\
\hline
\end{tabular}




\begin{tabular}{|l|c|c|c|c|l|l|}
\hline & $\begin{array}{c}\text { Kont } \\
\text { rol }\end{array}$ & 136,87 & 20,997 & & & \\
\hline
\end{tabular}

Dari hasil perhitungan tersebut diperoleh nilai Asymp. Sig. (2-tailed) lebih kecil dari taraf signifikansi $\quad 0,05 \quad(0,000<0,05) . \quad$ Dengan demikian, hipotesis ketiga pada penelitian ini dapat diterima, dimana terdapat perbedaan yang signifikan pada self management siswa dalam belajar antara kelompok eksperimen yang mengikuti layanan penguasaan konten menggunakan strategi problem solving dan self management siswa dalam belajar kelompok kontrol yang mengikuti layanan penguasaan konten secara konvensional.

\section{PEMBAHASAN}

Pada bagian ini akan dikemukakan pembahasan hasil temuan penelitian mengenai self management siswa dalam belajar melalui layanan penguasaan konten menggunakan strategi problem solving.

1. Perbedaan Self Management Siswa dalam Belajar Kelompok Eksperimen (Pretest dan Posttest).

Berdasarkan pengujian hipotesis pertama, dapat disimpulkan bahwa terdapat perbedaan yang signifikan pada self management siswa dalam belajar kelompok eksperimen sebelum dan sesudah diberi layanan penguasaan konten menggunakan strategi problem solving. Self management siswa dalam belajar yang dimaksud dalam penelitian ini adalah self management dalam persiapan mengikuti pembelajaran, self management dalam proses pembelajaran, self management setelah proses pembelajaran. Pemahaman tersebut diperoleh melalui layanan penguasaan konten menggunakan strategi problem solving.

Belajar merupakan upaya untuk menguasai sesuatu yang baru. Hamzah B. Uno (2006:16) menjelaskan belajar sebagai perubahan perilaku yang terjadi setelah siswa mengikuti atau mengalami suatu proses belajar mengajar, yaitu hasil belajar dalam bentuk penguasaan kemampuan dan keterampilan tertentu. Artinya belajar merupakan tingkah laku secara relatif permanen dan potensial, terjadi sebagai hasil dari praktik atau penguatan (reinforced practice) yang dilandasi tujuan untuk mencapai tujuan tertentu.

$$
\text { Selanjutnya, Hamzah B. Uno }
$$
(2006:219) menambahkan bahwa manajemen diri adalah perilaku siswa yang bertanggung jawab terhadap pengaturan segala perilakunya sendiri dengan tujuan agar siswa bisa lebih mandiri, lebih indipenden, lebih mampu memprediksi masa depannya.

Siswa yang memiliki manajemen diri akan dapat belajar secara efektif. Siswa juga mampu menata alokasi waktu dan kegiatan belajar siswa akan terkontrol sehingga tidak mudah terpengaruh oleh berbagai tantangan yang menghambat proses belajar, apalagi alokasi waktu tersebut disusun atas keinginan diri sendiri dan membuat komitmen untuk menjalankannya. Dengan demikian siswa akan mensugesti dirinya bahwa belajar yang baik merupakan sarana mencapai tujuan atau cita-cita yang diimpikan.

Meningkatkan self management siswa dalam belajar akan lebih efektif jika menggunakan strategi pembelajaran, agar proses belajar menjadi lebih efektif. Dengan demikian, cara peneliti untuk meningkatkan self management siswa dalam belajar adalah dengan cara memberikan layanan penguasaan konten menggunakan strategi problem solving. Penggunaan strategi problem solving dapat membantu siswa lebih terampil dan mandiri dalam meningkatkan self management dalam belajar dengan memecahkan masalah-masalah yang mereka hadapi dan kemudian mencari solusi terbaik atas permasalahan tersebut.

Meningkatkan self management siswa dalam belajar merupakan salah satu tugas dan tanggung jawab guru BK atau konnselor sekolah. Adapun bantuan yang diberikan dapat melalui layanan $\mathrm{BK}$, diantaranya layanan penguasaan konten. Pemberian layanan penguasaan konten (PKO) merupakan layanan bantuan kepada individu (sendiri ataupun kelompok) untuk menguasai kemampuan atau kompetensi tertentu melalui kegiatan belajar (Prayitno, 2012:89).

Pada penelitian ini, pembelajaran problem solving yang dilaksanakan melalui enam prosedur, yaitu mendefinisikan masalah, mendiagnosis masalah, merumuskan alternatif strategi, menentukan dan menerapkan strategi, dan skenario kegiatan belajar mengajar. Dalam penggunaan strategi pembelajaran ini tidak hanya menjadikan siswa aktif, melainkan menjadikan siswa lebih mandiri dan terampil dalam mencapai tujuan dalam belajar.

Keberhasilan pemberian layanan penguasaan konten menggunakan strategi problem solving diperkuat dengan hasil temuan pada hipotesis pertama yang menyatakan bahwa terdapat perbedaan yang 
signifikan pada self management siswa dalam belajar kelompok eksperimen sebelum dan sesudah diberikan layanan penguasaan konten menggunakan strategi problem solving. Hal ini ditunjukkan dengan adanya peningkatan hasil rata-rata skor kelompok eksperimen dari 137,40 menjadi 162,37. Adanya peningkatan rata-rata skor self management siswa dalam belajar kelompok eksperimen diduga diperoleh dari kebermaknaan proses pembelajaran yang dialami oleh siswa.

Berdasarkan hal yang telah dijelaskan di atas, maka layanan penguasaan konten menggunakan strategi problem solving dapat diberikan dalam rangka meningkatkan self management siswa dalam belajar. Dengan adanya layanan penguasaan konten menggunakan strategi problem solving, menjadikan siswa lebih efektif dalam proses pembelajaran terutama dalam memecahkan masalah yang berkenaan dengan merumuskan tujuan dalam proses pembelajaran.

2. Perbedaan Self Management Siswa dalam Belajar Kelompok Kontrol (Pretest dan Posttest).

Hipotesis kedua pada penelitian ini dapat diterima, dimana tidak terdapat perbedaan yang signifikan pada self management siswa dalam belajar kelompok kontrol secara konvensional. Dikatakan tidak signifikan karena hanya terjadi perbedaan mean sebelum dan sesudah diberi perlakuan, sementara tidak terjadi perbedaan kategori.

Layanan penguasaan konten dalam meningkatkan self management siswa dalam belajar kelompok kontrol diberikan secara konvensional, yaitu teknik dengan teknik ceramah dan tanya jawab. Senada dengan pernyataan tersebut, metode atau teknik yang digunakan dalam penyajian layanan PKO menurut Prayitno (2012:97) adalah penyajian dan tanya jawab.

Pemberian layanan penguasaan konten dengan metode konvensional ini menyajikan materi yang sama diberikan apada kelas eksperimen. Konten self management dalam belajar yang diberikan meliputi mempersiapkan fisik dalam belajar, mempersiapkan alat dan bahan belajar, memanfaatkan waktu belajar dan mengerjakan tugas, serta memberi penguatan pada diri sendiri.

3. Perbedaan Self Management Siswa dalam Belajar Kelompok Eksperimen dan Kelompok Kontrol.

Hasil penelitian menunjukkan bahwa terdapat perbedaan yang signifikan pada self management dalam belajar kelompok eksperimen yang diberi layanan penguasaan konten menggunakan strategi problem solving dengan kelompok kontrol yang diberi perlakuan layanan penguasaan konten secara konvensional. Self management dalam belajar yang dimaksudkan dalam penelitian ini adalah self management pada persiapan belajar, self management saat proses belajar, dan self management setelah proses belajar (Vinda Chairunnisa, 2013:39).

Untuk melihat perbedaan self management dalam belajar pada masingmasing kelompok, diberikan posttest sesudah pemberian perlakuan selesai. Hasil posttest kelompok eksperimen pada 30 orang siswa menunjukkan self management siswa dalam belajar berada pada kategori sangat baik sebanyak 2 orang, kategori baik sebanyak 24 orang, dan kategori cukup baik sebanyak 4 orang. Hasil rata-rata skor posttest self management siswa dalam belajar pada kelompok eksperimen sebesar 162,37 yang berada pada kategori baik. Selanjutnya hasil posttest kelompok kontrol pada 30 orang siswa menunjukan self management siswa dalam belajar berada pada kategori baik sebanyak 8 orang, pada kategori cukup baik sebanyak 18 orang, dan pada kategori tidak baik sebanyak 4 orang. Hasil rata-rata skor posttest self management siswa dalam belajar pada kelompok kontrol sebesar 136,87 yang berada pada kategori cukup baik.

Berdasarkan hasil uji statistik juga menunjukkan adanya perbedaan self management siswa dalam belajar pada kelompok eksperimen dan kelompok kontrol. Selanjutnya, untuk menentukan kelompok mana yang mengalami peningkatan lebih tinggi pada self management siswa dalam belajar, dapat melihat besarnya rata-rata skor pada masing-masing kelompok. Rata-rata skor self management siswa dalam belajar kelompok eksperimen lebih tinggi dibandingkan dengan rata-rata skor self management siswa dalam belajar kelompok kontrol, dimana rata-rata skor kelompok eksperimen sebesar 162,37 dan rata-rata skor kelompok kontrol sebesar 136,87.

Perbedaan self management siswa dalam belajar terjadi karena adanya perbedaan perlakuan yang diterima oleh masing-masing kelompok, walaupun materi dan banyaknya perlakuan yang diberikan sama-sama berjumlah 6 kali pertemuan. Kelompok eksperimen diberikan perlakuan layanan penguasaan konten menggunakan strategi problem solving, sementara kelompok kontrol diberikan perlakuan layanan penguasaan konten secara konvensional. 
Pada kelompok eksperimen, pemberian layanan penguasaan konten menggunakan strategi problem solving dilakukan dengan membagi anggota kelas menjadi beberapa kelompok. Pembagian kelompok dilakukan untuk membahas permasalahan yang berkaitan dengan konten yang telah ditentukan, sehingga tugas yang diberikan dapat dipecahkan dengan diskusi kelompok. Kemudian, hasil diskusi kelompok tersebut dibahas lagi dalam kelompok besar dan terakhir melaporkan hasil diskusi yang dibahas secara bersama-sama.

Strategi problem solving menggambarkan salah satu strategi pembelajaran aktif, inovatif, kritis, kratif, dan menyenangkan. Kegiatan-kegiatan dalam layanan penguasaan konten dengan strategi problem solving ini menjadikan siswa aktif dalam proses pembelajaran yang dialaminya. Hal ini disebabkan adanya komponen-komponen dalam strategi problem solving yang membantu siswa dalam proses pembelajaran.

Selanjutnya, pada kelompok kontrol diberikan perlakuan berbeda dari kelompok eksperimen yaitu pemberian layanan penguasaan konten secara konvensional. Peneliti memberikan konten-konten mengenai self management dalam belajar dengan teknik ceramah dan tanya jawab. Setelah peneliti memberikan konten dengan teknik ceramah, kemudian peneliti mempersilahkan siswa untuk bertanya apabila terdapat hal yang belum dipahami. Sebelum menjawab beberapa pertanyaan dari siswa, pertanyaan tersebut terlebih dahulu dilemparkan ke anggota kelompok lainnya dengan tujuan agar siswa-siswa yang lain ikut berpikir mengenai pertanyaan yang dikemukakan.

\section{KESIMPULAN}

Berdasarkan data dan hasil penelitian yang telah diperoleh, secara khusus dapat ditarik kesimpulan sebagai berikut.

1. Terdapat perbedaan yang signifikan pada self management siswa dalam belajar untuk kelompok eksperimen sebelum dan setelah dilaksanakan layanan penguasaan konten menggunakan strategi problem solving.

2. Terdapat perbedaan self management siswa dalam belajar pada kelas kontrol, namun secara keseluruhan tidak mengalami peningkatan. Adapun beberapa yang mengalami peningkatan pada self management dalam belajar tetapi tidak memberi perbedaan yang signifikan.

3. Terdapat perbedaan yang signifikan pada peningkatan self management siswa dalam belajar pada kelompok eksperimen yang diberi perlakuan layanan penguasaan konten menggunakan strategi problem solving dengan kelompok kontrol yang diberi perlakuan layanan penguasaan konten secara konvensional (tanpa menggunakan strategi problem solving).

Dari rata-rata hasil pengolahan data dengan teknik uji beda (t-test) menggunakan bantuan program Statistical Product and Service Solution (SPSS) versi 20.0 dan Microsoft Excell 2007diketahui bahwa pada kelompok eksperimen memiliki peningkatan yang lebih besar dibandingkan kelompok kontrol.

\section{SARAN}

Berdasarkan hasil penelitian yang telah dipaparkan di atas, maka dapat dikemukakan saran sebagai berikut:

1. Guru bimbingan dan konseling diharapkan agar membantu dan membimbing siswa dalam meningkatkan self management dalam belajar melalui layanan penguasaan konten menggunakan strategi problem solving.

2. Kepada kepala sekolah diharapkan kerjasamanya dalam alokasi jam BK di sekolah. Untuk pelaksanaan layanan BK khususnya layanan penguasaan konten, waktu minimal yang dibutuhkan adalah dua jam pelajaran ( $2 \times 45$ menit).

3. Kepada Kepala Dinas Pendidikan Kota Padang diharapkan dapat membantu memfasilitasi guru BK atau konselor sekolah dalam meningkatkan kemampuan pengembangan keterampilan konseling, terutama dalam pelaksanaan layanan penguasaan konten dengan pendekatan problem solving ataupun pendekatan lainnya.

4. Kepada peneliti selanjutnya, perlu dilakukan penelitian yang serupa dengan jumlah sampel yang lebih luas yang berasal dari beberapa sekolah. Selain itu juga perlu dilakukan penelitian yang dilatarbelakangi oleh konteks atau variabel yang berbeda agar dapat membandingkan temuan dari penelitian ini serta sekaligus memperdalam, memperjelas, dan memberikan temuan yang terbaru terkait dengan self management siswa dalam belajar.

\section{KEPUSTAKAAN}

Agus Irianto. 2004. Statistik: Konsep Dasar, Aplikasi dan Pengembangannya. Jakarta:Prenada Media Group.

Anas Sudjono. 2007. Pengantar Evaluasi Pendidikan. Jakarta: Raja Grafindo. 
Hamzah B. Uno. 2006. Orientasi Baru dalam Psikologi Pembelajaran. Jakarta: PT. Bumi Aksara.

John W. Santrock. 2007. Remaja (Alih Bahasa: Benedictine Widyasinta).Jakarta: Erlangga.

Prayitno. 2004. Seri Layanan Konseling: Layanan Informasi (L-2). Padang: UNP Press.
Riduwan. 2004. Belajar Mudah pada Penelitian untuk Guru, Karyawan dan Peneliti Pemula. Bandung: Alfa Betta.

Suharsimi Arikunto. 2009. Prosedur Penelitian: Suatu pendekatan praktek. Bandung: Rineka Cipta.

Vinda Chairunnisa. 2013. Hubungan Antara Manajemen Diri dengan Hasil Belajar Siswa. Skripsi. Padang : BK FIP UNP.

Prayitno. 2012. Jenis Layanan dan Kegiatan Pendukung Konseling. Padang: BK FIP UNP. 